\title{
EDMODO GO BLOG
}

\author{
Rini Ekayati ${ }^{1 *}$, Muhammad Arifin ${ }^{1}$ \\ ${ }^{I}$ Faculty of Teachers Training and Education, University of Muhammadiyah Sumatera Utara, Medan, Indonesia \\ *Corresponding Author: riniekayati@umsu.ac.id
}

\begin{abstract}
The main issue laid behind this community service program is the fact that there is still low quality of learning and teaching activities which currently faced by Muhammadiyah schools in Binjai. This condition affects the quality of learning which is not optimally conducted, and so produce less than maximum learning results. Moreover, the development of science and technology now days affects the situation as well, where science and technology has been used in learning through the use of information-technology-based (IT-based) media. A training program on how to accommodate ITbased media is one solution offer to overcome this situation. The training materials provided include on making virtual classroom learning using Edmodo application, and connecting Edmodos with Blog in learning. This activity was held in Muhammadiyah complex building with 21 participants. Lecturing, discussions, and direct practice are the methods used in this program. At the end of the program, the participants had changed in the way they carried out their tasks in the class that have been utilizing IT-based media, so that the learning process is more qualified. This results shows that there is an improvement in the quality of teaching and learning process at Muhammadiyah schools in Binjai as program partners.
\end{abstract}

Keywords: information technology-based media, Edmodo, Blog

\section{INTRODUCTION}

The demand to improve the quality of teaching and learning process will be more severe in the future. This is the impact of the development of the world of technology and information today. The need to increase skills, including teaching skills in the learning process will be more urgent. In addition, there has been a shift in the paradigm of learning that collaborated with traditional methods with internetbased methods or better known as e-learning.

This Science and Technology Program for the Community Service (IbM) activity was held in Binjai , especially at the Muhammadiyah school. There are 12 units of Muhammadiyah schools in Binjai, which can be seen in the following table:

\begin{tabular}{|l|l|l|}
\hline $\begin{array}{c}\text { School } \\
\text { Name }\end{array}$ & \multicolumn{1}{|c|}{ Address } & \multicolumn{1}{|c|}{ Principal } \\
\hline SD M 01 & $\begin{array}{l}\text { Jl. Kartini No. 25 } \\
\text { Binjai Kota }\end{array}$ & Suhardiyansah, STHI \\
\hline SD M 02 & $\begin{array}{l}\text { Jl. D. Tempe No. 40 } \\
\text { Binjai Timur }\end{array}$ & Ramli, S. Pd \\
\hline SD M 03 & $\begin{array}{l}\text { Jl. Perintis } \\
\text { Kemerdekaan Binjai } \\
\text { Utara }\end{array}$ & M. Fauzi, S. PdI \\
\hline SD M 04 & Jl. MT. Haryono & Aulia Rahman, S. PdI \\
\hline SD M 05 & Jl. Amir Hamzah & Rahmad Edi, S. PdI \\
\hline SMP M 12 & $\begin{array}{l}\text { Jl. K.H. Ahmad } \\
\text { Dahlan No. 4 Binjai } \\
\text { Kota }\end{array}$ & Drs. Fuad \\
\hline SMP M 56 & $\begin{array}{l}\text { Jl. D. Tempe No. 40 } \\
\text { Binjai Timur }\end{array}$ & Tulus, S. Pd \\
\hline MTs M 18 & Jl. Tj. Pura Sp. Kwala & Waliadi, S. Ag \\
\hline
\end{tabular}

\begin{tabular}{|l|lr|l|}
\hline & Madu & \\
\hline MTs M 27 & $\begin{array}{l}\text { Jl. } \\
\text { Kemerdekaan Berintis } \\
\text { Utara }\end{array}$ & Buhari, S. Ag \\
\hline SMA M 12 & $\begin{array}{l}\text { Jl. K.H. Ahmad } \\
\text { Dahlan No. 4 Binjai } \\
\text { Kota }\end{array}$ & Dra. Nurainun \\
\hline MA M 15 & $\begin{array}{l}\text { Jl. } \\
\text { Kemerdekaan Berintis } \\
\text { Utara }\end{array}$ & Juriadi, S, PdI, MA \\
\hline MA M 18 & $\begin{array}{l}\text { Jl. Tj. Pura Sp. Kwala } \\
\text { Madu }\end{array}$ & Azar Aswadi, MA \\
\hline
\end{tabular}

Figure 1. List of Muhammadiyah School

(Source: Majelis Dikdasmen PDM Kota Binjai)

Schools now days have been facilitated by the internet working space, like some schools in Binjai city, especially schools under the Muhammadiyah. At least, there are $75 \%$ Muhammadiyah's schools that have been facilitated by Wi-Fi. However, the existence of this facility cannot be utilized optimally, especially by the teacher to create a better quality learning situation.

This is one of the problems faced by teachers who are teaching in schools of Muhammadiyah Binjai. This facility is not optimally used due to lack of training in IT-based learning method. This is the urgent situation that needs to be overcome directly. One of the efforts is by conducting a training program in using online media applications such as Edmodo collaborated with Blog as a form of utilization of available network facilities. 


\section{MATERIALS AND METHODS}

Education as the pillar of a nation need continuously be improving its quality at every level of education. In the process, teacher is one of the big factors needed to be update in term of their competence and performance to develop a curriculum that corresponds to the current developments. Following the development in information and technology, it is needed to create programs that can play in improving the competence of educators. Through Science and Technology Program for the Community Service $(\mathrm{IbM})$, team create and design a training program to design a internet-based media via Edmodo application elaborate with Blog to improve the ability of teachers, especially at Muhammadiyah schools, Binjai. Material like infocus, laptop, internet connection, e-mail account, and handbook was prepared by the team to accommodate the need of training program. The material provided during the program was arranged.

In conducting the program, there were some implementation methods that were applied before and after the execution of the program. All of the procedure is explain below:

1. Initial Approach

In conducting the training activities, the initial approaches done by the team are coordination between the team with partners to design the form of the training activities that will be conducted, the implementation of training activities on techniques to design and manage online learning media using Edmodo application collaborated with Blog, optimizing the facilities and infrastructure available at partners' location, and facilitating the simulation of the use of internet network in learning especially on the use of the internet as a media of learning.

2. Program Procedure

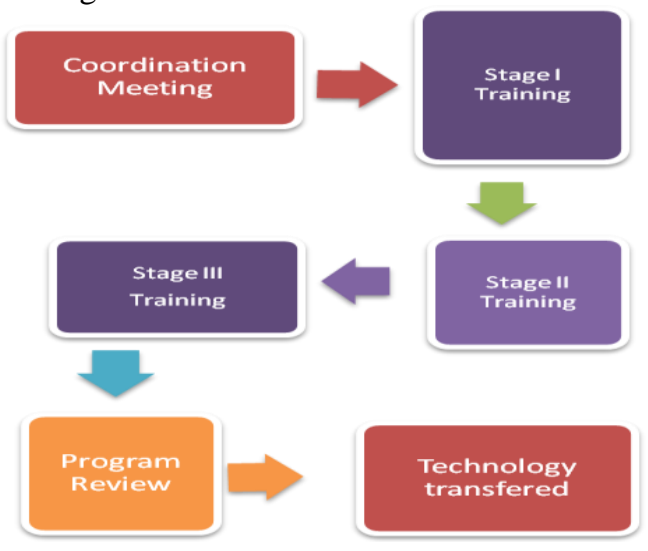

Figure 2. Program Procedure

\section{Training Activity}

There were some methods which were being collaborated during the training activity session. Lecturing method used in the process of delivering training materials, giving motivation to teachers as to improve performance and eager to innovate new method and media in learning in order to maximize learning outcomes.

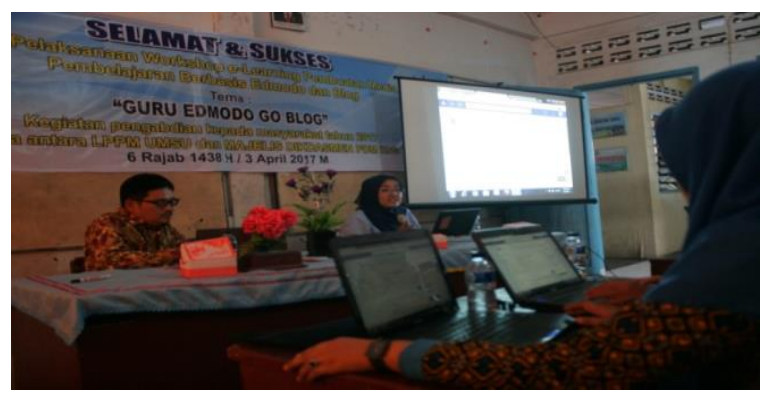

Figure 3. Material Presentation About Edmodo and $\mathrm{B} \log$

The second method was discussion which was used as a medium of communication during the course of the training. Teacher and trainer can communicate to each other. There was also a question session which was used to confirm if there was something not understood related to the material delivered during the training. Last, there was a direct practice methods implemented to ensure that science and technology has been transferred to all participants in accordance with the program purposes and targets. All of the session was conducted by supervision from the mentor.

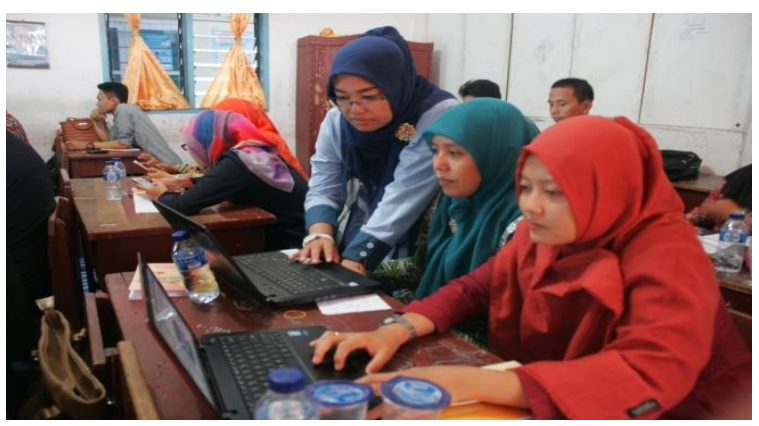

Figure 4. The Direct Practice Session

\section{Supervision Stage}

The supervision stage is done by monitoring and forming the Edmodo community in the partner location where the teacher can carry out the learning activities by exchanging experience in using Edmodo application properly and systematically until finally they are able to improve and develop their capacity and quality in performing teaching and learning task in the future.

\section{RESULTS AND DISCUSSION}

The program was held on $03^{\text {rd }}$ April 2017 at the PDM Office of Binjai. Initially each participant was introduced to an IT-based learning application, Edmodo, and continued by creating an Edmodo account for teachers to design a virtual world class through the link www.edmodo.com. For most participants, the Edmodo app is a new app they know. This arouses curiosity and adds to the 
enthusiastic value of participants in following the material. After each participant has their own Edmodo account, then the tutor guides the participants to arrange their own classes, such as creating classes based on the subject they are studying, and adding students to their virtual class in Edmodo. The tutor also explains how to use each features of the Edmodo app like an online test or quiz.

After all the participants finished managing their Edmodo class, the next material is about Blog. The participants were given an introduction of the material about Blog. Mostly all participants just heard the term 'blog' for the first time. This led to the enthusiasm and high spirits of the participants in following this session. After the material was completed, the participants again guided by the tutor created their own Blog. Each participant registers via www.blogger.com link by using gmail.com account to have their own personal blog. After each participants has their own blogs, then the tutor conducted a simulation of learning by using virtual class by Edmodo app and Blog. The simulation ran for around 10 minutes for each participant. The simulation session is the end of a series of the training activities. Furthermore, this series of IbM activities will be continued by monitoring and evaluation of the programs that have been implemented.

By the explanation above, this Science and Technology Program for the Community Service (IbM) resulted in the change of the way teachers carried out their tasks in the class that have been utilizing IT-based media, so that the learning process is more qualified. It meant that there was an improvement of the quality of the teaching and learning process in the class. Based on the first observation, team figured out for most teachers teaching by utilizing IT-based media like Edmodo was their first experience. Even, there was still a teacher do not have an e-mail account as one of the requirement to get Edmodo account. It indicated that for some teacher teaching via internet network was a new thing. This situation was challenging.

Moreover, Edmodo here was run assisted by another form of web media that is Blog. Just like Edmodo, Blog is also a new thing for some teachers. In fact, there were some other teachers who already have a blog, but rarely update their blogs. This situation resulted in a different achievement for each individual of the teacher as the participants. For two until four teacher, IT-based media like Edmodo and Blog was not so difficult to understand. They only need to understand how to apply them in their teaching and learning process. In fact, for other teachers, it was not that easy. Took sometimes to make them started to understand what IT-based media means, what is Edmodo, and last what is Blog.
As one of the solution to overcome this, team already prepared a handbook that can be used by the participant as their guidance. By following the explanation of step by step process of applying Edmodo and Blog as the IT-based media in teaching and learning from the book, and also assisted by the mentor during the training, all of the participants can follow the training program more easily. Later, the handbook is one of the other outputs of this Science and Technology Program for the Community Service (IbM).

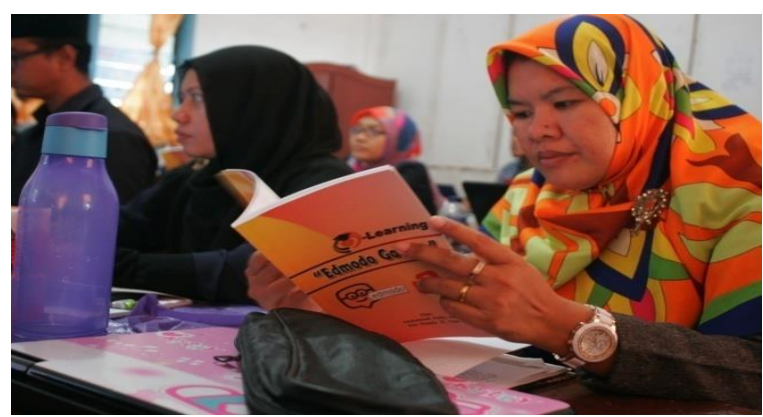

Figure 5. Perticipant is Reading the Handbook during the Training

During the practice session, participants and mentor were getting involved in two-ways dialogue. Based on the observation, the participants were excited about the new knowledge they get from the training. Further, the success of the participants in applying the material can be seen from their respond of the training program. At the end, each of the participants were asked to do demonstration of using Edmodo and Blog in front of the audience. It was a simulation of the real teaching and learning by using this IT-base media later on their class. All of the participants were involved in this session. This can be as an indicator that there is an improvement in the quality of teaching and learning process at Muhammadiyah schools in Binjai as program partners.

In accordance with the planned achievements of this IbM program, as for the output of the program, this activity produced publications in printed media, Waspada, edition Thursday $06^{\text {th }}$ April, 2017 and textbooks with ISBN.

\section{CONCLUSION}

In accordance with the purpose of the implementation of this program, the conclusions that can be obtained from the implementation of Community Service Program "Edmodo Go Blog" is a change that occurs in partners capacity, in this case teachers of Muhammadiyah schools, Binjai, related to their ability from previously unable to use e-learning method, has now been able to use it with the help of Edmodo and Blog applications. 


\section{ACKNOWLEDGEMENT}

The authors are grateful to University of Muhammadiyah Sumatera Utara, through The Research Institutes and Community Service that have rolled out the internal funding to the IbM program; to the Dean of Faculty of Teachers Training and Education, UMSU who has supported the implementation of this activity; to the DIKDASMEN assembly Binjai and all participants who were being actively involved in the training program; and to all team members who have worked together for the smoothness of this activity from the beginning until the end.

\section{BIBLIOGRAPHY}

Basori. 2013. Pemanfaatan Social Learning Network "Edmodo" Dalam Membantu Perkuliahan Teori Bodi Otomotif Di Prodi PTM JPTK FKIP UNS. JIPTEK, Vol. VI No.2, Juli 2013. Hal 99-105

Effendi, Mukhlison. 2013. Integrasi Pembelajaran Active Learning dan Internet-Based Learning dalam Meningkatkan Keaktifan dan Kreativitas Belajar. Nadwa: Jurnal Pendidikan Islam, Vol. 7, Nomor 2, Oktober 2013. Hal. 283-308

Ekayati, Rini. 2016. Optimalisasi Edmodo Dalam Meningkatkan Kemandirian Belajar dan Kesadaran Berbahasa Mahasiswa Semester VII Pada Mata Kulian LC Di Prodi Pendidikan Bahasa Inggris FKIP UMSU. Laporan Penelitian Teaching Grant, LPPM UMSU. Medan

Haris, Panduan Edmodo Bagi Teacher, Materi Pelatihan Elearning bagi dosen dan Mahasiswa Universitas Darussalam Ambon, 2014.

Kompas, Senin 23-2-2015, Sekolah Masih KhawatirSosialisasi Format UN Daring Ditunggu-hal 11

Kompas, Kamis, 26-2-2015, Semidaring tidak Merugikan-UN 7-20 April, hal 11 